\title{
Factors for Delay in LRT Bridge Structure Work
}

\author{
Maulana Abidin ${ }^{1}$ Nunung Widyaningsih ${ }^{2}$ \& Bambang Purwoko Kusumo Bintoro ${ }^{3}$ \\ ${ }^{1}$ Department Master Program of Civil Engineering \\ Mercu Buana University \\ Jakarta Indonesia \\ ${ }^{2-3}$ Department Master Program of Civil Engineering \\ Mercu Buana University \\ Jakarta Indonesia
}

\begin{abstract}
In order to increase economic growth through infrastructure development in Indonesia, the Government accelerates projects that are considered strategic and have high urgency to be realized in a short period of time. The construction of the Jabodebek LRT project has taken almost four years since 2015. The government has targeted the project to be completed in April 2019, but the realization has been delayed, which is only around 50\%. For this reason, the researcher wants to discuss the factors that delay the construction work of the LRT bridge structure. The following results from data processing using RII analysis: 1. Weak planning and project scheduling by contractors, 2. Project time optimization, 3. Ineffective planning and scheduling, 4. Determination of duration, 5. Contractors who lack experience, 6. Weak communication and coordination by service users during construction, 7. Different surface conditions of subsoil, 8. Solid traffic, crowds and other disturbances in the field, 9. Low quality of project control and 10. Lack of control. It is expected that from the results of the above data analysis it can contribute to the construction world, especially the construction of the LRT project.
\end{abstract}

Key Words: LRT, Delay Time, Bridge Structure, RII

\section{INTRODUCTION}

The construction of the Jabodebek LRT project has taken almost four years since 2015. The government has targeted the project to be completed in April 2019, but the realization has been delayed, which is only around 50\%. So far, the development of the phase I Jabodebek LRT project until January 2019 has reached 56.1\%. The construction of Phase I of the Jabodebek LRT stretched from Cawang-Cibubur (76.21\%), Cawang-Kuningan-Dukuh Atas (44.19\%) and Cawang-Bekasi (51.06\%). LRT Jabodebek itself has a track length of $44.3 \mathrm{KM}$.

\section{SCHEDULING}

Scheduling planning is intended so that the implementation of the work becomes efficient and effective so that there are no problems due to delayed work because it is not well planned. Effectiveness and efficiency in project implementation is influenced by factors Planning and scheduling. According to Haming and Nurnajamuddin [1] scheduling is the allocation of resources from time to time to support the implementation and completion of a specific work activity. Determining the allocation of company resources (human resources, capacity and production equipment or machinery, and time resources) is shown to realize the target of effective and efficient use of resources, while producing the right amount of output, on time, and right quality [2,3]

\section{DELAY}

Delays can be considered as a result of not meeting the schedule plan that has been made, because the reality is not in accordance with the conditions when the schedule was made. Proboyo (1998) explains that the project planning and scheduling process thus needs to understand all the factors behind the project schedule [4]. Project delays can be seen in two things as mentioned above, namely the aspects that are affected and the factors that influence or cause. The factors that are affected that cause the project to be late are: Delay related to material, Delay related to labor, Delay related to equipment, Inappropriate planning, Weak control of project time, Subcontractor Delay, Weak coordination, Inadequate supervision, Inappropriate implementation method, Lack of technical personnel \& Weak communication. 


\section{TIME}

In order for the project to run smoothly and effectively, it is necessary to set the time or scheduling of the activities involved in it. In connection with this, the executor of a project usually creates a time schedule [5]. Timetable for activities is work sequences that contain, among others: the type of work to be carried out and the time when a job starts and ends. In the implementation of the project a time analysis must be carried out, because time analysis is the first step before conducting a resource analysis and cost analysis. What is meant by time analysis is studying the behavior of the activities during the implementation of the project [6]. The purpose of time analysis in project management is to reduce the level of uncertainty in the implementation time during the project implementation, thus the exact timing can be determined priority scale at each stage. Another benefit of this time analysis is that an efficient way of working can be done, so that the implementation time of the project is also efficient. [7]

\section{LIGHT RAIL TRANSIT (LRT)}

Light Rail Transit (LRT) is an example of the progress of land transportation in the field of railways and LRT is one of the alternative feeder modes for the MRT. In order to meet the progress of land transportation in the railroad sector in Indonesia, the railroad manufacturing company is planning to build a LRT prototype as an MRT feeder mode and an initial example for the actual LRT manufacturing. The main construction of the LRT is like a train in general, which is located in the underframe construction. Light Rail Transit (LRT) is one of the mass transportation that uses electricity as its driving force, has a large capacity and has its own lane [8].

\section{RESEARCH METHOD}

The research method is basically a scientific way to get data with specific purposes and uses. To achieve the required goals, a relevant method is needed to achieve the desired goals [9]. According to research methods [10] is basically a scientific way to get valid data with objectives that are discovery, proof and development of a knowledge so that the results can be used to understand, solve and anticipate problems. The flow in this study is:

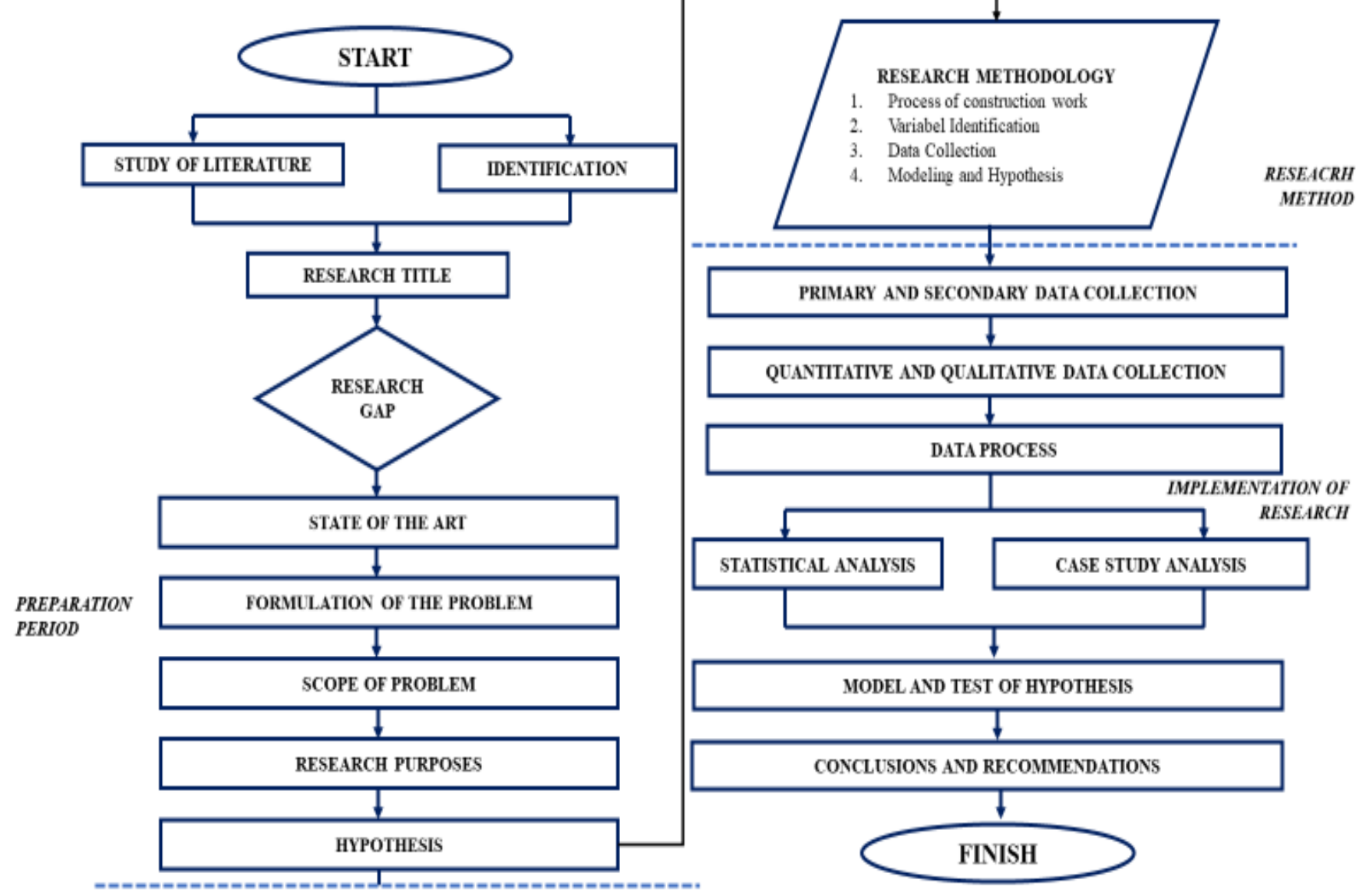

Figure 1. Research Flow 
from the above research methods explain the research steps used. where in researching about scheduling delays requires primary data and secondary data in processing it.

\section{IDENTIFICATION OF VARIABLES}

This study has 3 independent variables and 2 dependent variable for processing and analyzing the results of factors for delay in LRT bridge structure work. variables can be in the form of theory or object of research. These variables are:

- Dependent Variabel : 1. Scheduling (X1)

2. Productivity (X2)

- Independent Variabel : - Time (Y1)

3. LRT Bottom Structure (X3)

- Quality (Y2)

Independent and dependent variables in the regression equation:

$$
\mathrm{Y}=\mathbf{a}+\mathbf{b} . \mathbf{X} 1+\mathbf{c} . \mathrm{X} 2+\mathbf{d} . \mathrm{X} 3
$$

Variable identification is obtained from the key success factors obtained from journals, books, e-books and other references respondents obtained from this study were 70 respondents. Determination of the number of respondents using the Slovin method. Where to use the target population, the target population is the number of respondents according to the project organizational structure. The following are influential factors:

Table 1. Factors for delay LRT bridge structure work

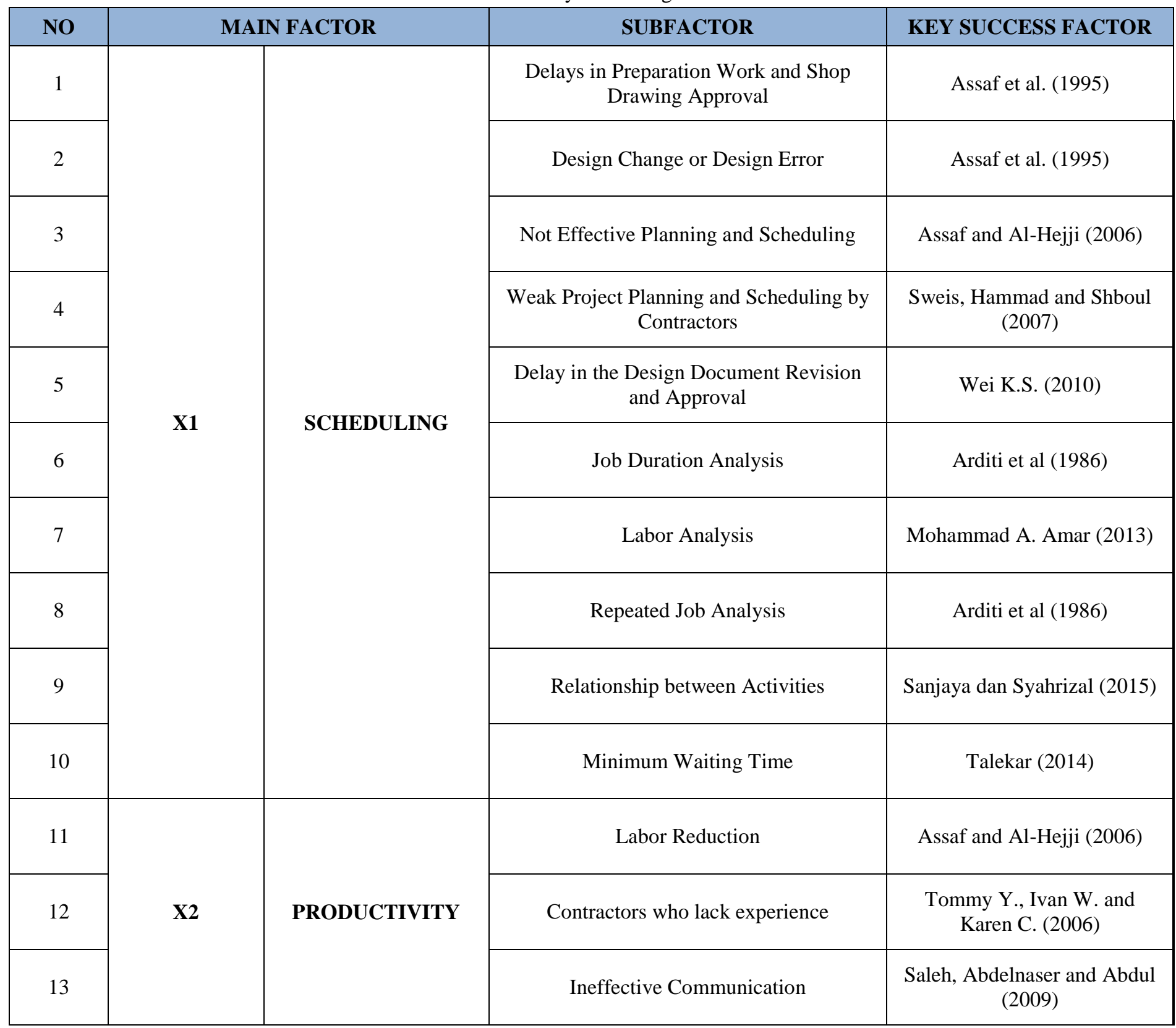


International Journal of Engineering Research And Advanced Technology, Vol.5, Issue 7, July-2019

\begin{tabular}{|c|c|c|}
\hline 14 & $\begin{array}{c}\text { Delay in sending materials such as steel, } \\
\text { concrete etc. }\end{array}$ & $\begin{array}{l}\text { Saleh, Abdelnaser and Abdu } \\
\text { (2009) }\end{array}$ \\
\hline 15 & $\begin{array}{c}\text { Weak Communication and Poor } \\
\text { Coordination by Service Users during } \\
\text { Construction } \\
\end{array}$ & Wei K.S. (2010) \\
\hline 16 & Innovative ways of thinking & Verduyn (2002) \\
\hline 17 & Unclear details & Assaf et al (2006) \\
\hline
\end{tabular}

[ADVANCED - TABLE.1]

\begin{tabular}{|c|c|c|c|c|}
\hline NO & \multicolumn{2}{|c|}{ MAIN FACTOR } & SUBFACTOR & KEY SUCCESS FACTOR \\
\hline 18 & \multirow{3}{*}{$\mathbf{X} 2$} & \multirow{3}{*}{ PRODUCTIVITY } & Working Method Approach & Zakaria et al (2017) \\
\hline 19 & & & Work location & Kent et al (2000) \\
\hline 20 & & & Performance Integrity & Cooke et al (2002) \\
\hline 21 & \multirow{5}{*}{$\mathbf{X 3}$} & \multirow{5}{*}{$\begin{array}{l}\text { STRUCTURE } \\
\text { UNDER LRT }\end{array}$} & $\begin{array}{c}\text { Availability of Work Equipment as } \\
\text { needed, such as TBM, Launching Girder, } \\
\text { etc. }\end{array}$ & Mittal, Yash Kumar (2018) \\
\hline 22 & & & $\begin{array}{l}\text { Solid, crowded and other disturbances in } \\
\text { the field }\end{array}$ & Mittal, Yash Kumar (2018) \\
\hline 23 & & & Decreasing Groundwater Level & Sungmin (2009) \\
\hline 24 & & & Changes in Land Load and Land Area & Sungmin (2009) \\
\hline 25 & & & Different Underwater Layers & Sungmin (2009) \\
\hline 26 & \multirow{4}{*}{ Y1 } & \multirow{4}{*}{ TIME } & Previous Work Delay & Syahrizal et al, (2015) \\
\hline 27 & & & Project Time Optimization & Talekar (2014) \\
\hline 28 & & & Risk of Project Uncertainty & Egbu (1998) \\
\hline 29 & & & Occupational Complexity & Egbu (1998) \\
\hline
\end{tabular}


International Journal of Engineering Research And Advanced Technology, Vol.5, Issue 7, July-2019

\begin{tabular}{|c|c|c|c|c|}
\hline 30 & & & Determination of Time Duration & Chang (2002) \\
\hline 31 & & & Lack of Knowledge about Materials & Prianto (2012) \\
\hline 32 & $\mathbf{Y} 2$ & COST & Supplier Performance in Material Supply & Yoggeswaran et al (1998) \\
\hline 33 & & & Low Quality of Project Control & Koushki et al (2005) \\
\hline
\end{tabular}

[ADVANCED - TABLE.1]

\begin{tabular}{|c|c|c|c|c|}
\hline NO & \multicolumn{2}{|c|}{ MAIN FACTOR } & SUBFACTOR & KEY SUCCESS FACTOR \\
\hline 34 & \multirow{2}{*}{ Y2 } & \multirow{2}{*}{ COST } & Lack of Work Preparation & Brodetskaia et al (2011) \\
\hline 35 & & & Lack of Control & Love \& Swinney (1996) \\
\hline
\end{tabular}

from table 1 , we get the top 10 ranking of the factors that most influence the delay in the lower part of the lrt structure work using the RII method.

\subsection{RII METHOD}

Relative Importance Index (RII) is a terminology that was first published as stated in. RII is an analysis that allows a quantitative relative, where the higher the rating (rating) the higher the influence given by the variable under study. Having obtained the most dominant factors, eating will be sought to analyze the root causes of these factors. The analytical method used will depend on the results of the normality test data on the answers of all respondents received :

$$
R I I=\frac{\sum_{i=1}^{i=A} n_{i} \times i}{A \times N}
$$

This method is carried out with the aim of obtaining an index of the level of influence of each factor on the performance of the project in tiling finishing work in high-rise buildings. The range of RII values produced is between 0 and 1 .

Table 2. RII RANKING

\begin{tabular}{|c|c|}
\hline Range of RII Values & Rating \\
\hline $\mathbf{0 , 8 3 4}-\mathbf{1 , 0 0 0}$ & Very Dominant \\
\hline $\mathbf{0 , 6 6 8}-\mathbf{0 , 8 3 3}$ & Dominant \\
\hline $\mathbf{0 , 5 0 1}-\mathbf{0 , 6 6 7}$ & Rather dominant \\
\hline $\mathbf{0 , 3 3 4}-\mathbf{0 , 5 0 0}$ & Less dominant \\
\hline $\mathbf{0 , 1 6 8}-\mathbf{0 , 3 3 3}$ & Not Dominant \\
\hline $\mathbf{0 , 0 0 0}-\mathbf{0 , 1 6 7}$ & Very Dominant \\
\hline
\end{tabular}

The following variables have been added : 
International Journal of Engineering Research And Advanced Technology, Vol.5, Issue 7, July-2019

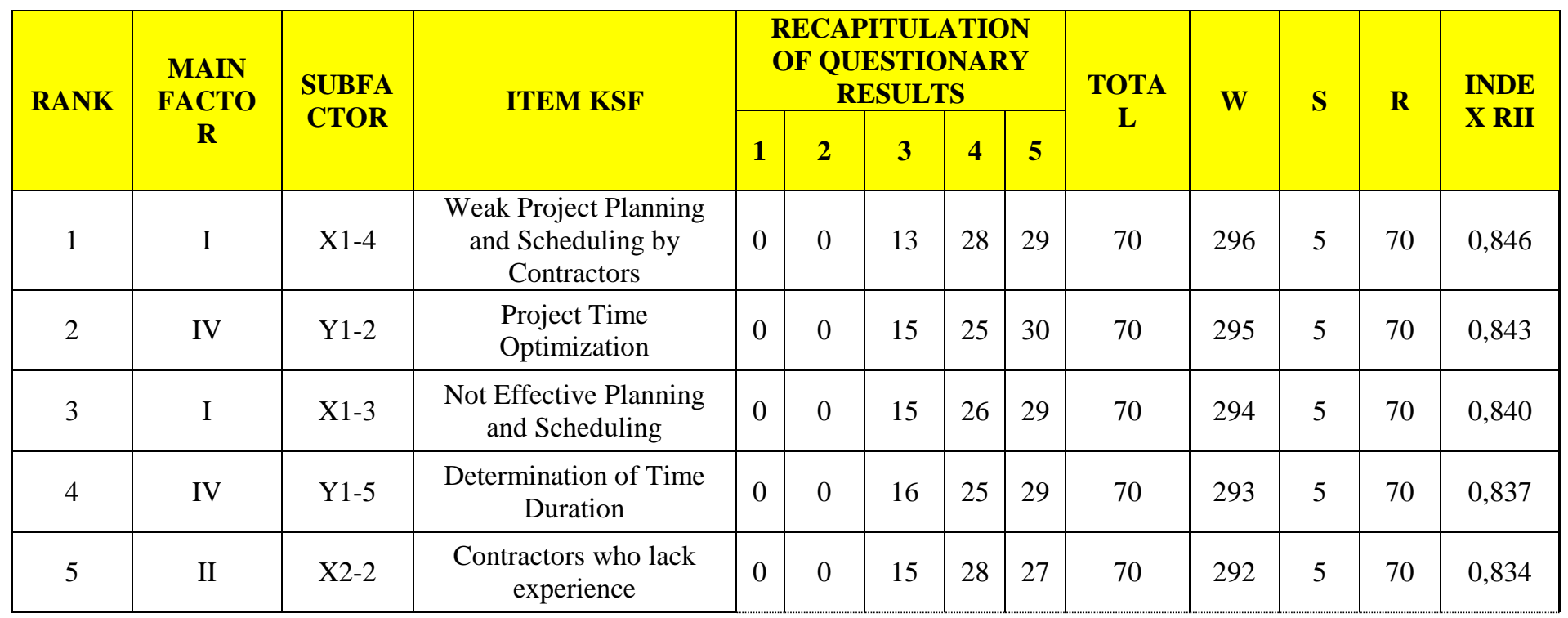

\begin{tabular}{|c|c|c|c|c|c|c|c|c|c|c|c|c|c|}
\hline \multirow[t]{2}{*}{ RANK } & \multirow{2}{*}{$\begin{array}{l}\text { MAIN } \\
\text { FACTO } \\
\quad \mathbf{R}\end{array}$} & \multirow{2}{*}{$\begin{array}{l}\text { SUBFA } \\
\text { CTOR }\end{array}$} & \multirow[t]{2}{*}{ ITEM KSF } & \multicolumn{5}{|c|}{$\begin{array}{l}\text { RECAPITULATION } \\
\text { OF QUESTIONARY } \\
\text { RESULTS }\end{array}$} & \multirow[t]{2}{*}{ TOTAL } & \multirow[t]{2}{*}{ W } & \multirow[t]{2}{*}{$\mathbf{S}$} & \multirow[t]{2}{*}{$\mathbf{R}$} & \multirow{2}{*}{$\begin{array}{l}\text { INDE } \\
\text { X RII }\end{array}$} \\
\hline & & & & 1 & 2 & 3 & 4 & 5 & & & & & \\
\hline 6 & II & $\mathrm{X} 2-5$ & $\begin{array}{c}\text { Weak Communication } \\
\text { and Poor Coordination } \\
\text { by Service Users during } \\
\text { Construction }\end{array}$ & 0 & 0 & 17 & 26 & 27 & 70 & 290 & 5 & 70 & 0,829 \\
\hline 7 & III & $X 3-5$ & $\begin{array}{l}\text { Different Underwater } \\
\text { Layers }\end{array}$ & 0 & 0 & 19 & 26 & 25 & 70 & 286 & 5 & 70 & 0,817 \\
\hline 8 & III & $\mathrm{X} 3-2$ & $\begin{array}{l}\text { Solid, crowded and other } \\
\text { disturbances in the field }\end{array}$ & 0 & 0 & 20 & 26 & 24 & 70 & 284 & 5 & 70 & 0,811 \\
\hline 9 & V & Y2-3 & $\begin{array}{c}\text { Low Quality of Project } \\
\text { Control }\end{array}$ & 0 & 0 & 22 & 25 & 23 & 70 & 281 & 5 & 70 & 0,803 \\
\hline 10 & V & Y2-5 & Lack of Control & 0 & 1 & 21 & 25 & 23 & 70 & 280 & 5 & 70 & 0,800 \\
\hline 11 & I & $\mathrm{X} 1-1$ & $\begin{array}{c}\text { Delays in Preparation } \\
\text { Work and Shop Drawing } \\
\text { Approval }\end{array}$ & 0 & 3 & 23 & 24 & 20 & 70 & 271 & 5 & 70 & 0,774 \\
\hline 12 & IV & Y1-1 & Previous Work Delay & 0 & 2 & 25 & 24 & 19 & 70 & 270 & 5 & 70 & 0,771 \\
\hline 13 & II & $X 2-6$ & $\begin{array}{c}\text { Innovative ways of } \\
\text { thinking }\end{array}$ & 0 & 2 & 25 & 25 & 18 & 70 & 269 & 5 & 70 & 0,769 \\
\hline 14 & II & $\mathrm{X} 2-8$ & $\begin{array}{l}\text { Working Method } \\
\text { Approach }\end{array}$ & 0 & 2 & 26 & 27 & 15 & 70 & 265 & 5 & 70 & 0,757 \\
\hline 15 & III & $\mathrm{X} 3-4$ & $\begin{array}{l}\text { Changes in Land Load } \\
\text { and Land Area }\end{array}$ & 0 & 4 & 26 & 24 & 16 & 70 & 262 & 5 & 70 & 0,749 \\
\hline 16 & V & Y2-4 & $\begin{array}{l}\text { Lack of Work } \\
\text { Preparation }\end{array}$ & 0 & 5 & 25 & 24 & 16 & 70 & 261 & 5 & 70 & 0,746 \\
\hline 17 & I & $\mathrm{X} 1-6$ & Job Duration Analysis & 0 & 3 & 28 & 25 & 14 & 70 & 260 & 5 & 70 & 0,743 \\
\hline 18 & II & $\mathrm{X} 2-4$ & $\begin{array}{c}\text { Delay in sending } \\
\text { materials such as steel, } \\
\text { concrete etc. }\end{array}$ & 0 & 3 & 27 & 27 & 13 & 70 & 260 & 5 & 70 & 0,743 \\
\hline 19 & II & $\mathrm{X} 2-10$ & Performance Integrity & 0 & 5 & 25 & 26 & 14 & 70 & 259 & 5 & 70 & 0,740 \\
\hline
\end{tabular}


International Journal of Engineering Research And Advanced Technology, Vol.5, Issue 7, July-2019

\begin{tabular}{|c|c|c|c|c|c|c|c|c|c|c|c|c|c|}
\hline 20 & IV & Y1-3 & $\begin{array}{l}\text { Risk of Project } \\
\text { Uncertainty }\end{array}$ & 0 & 6 & 25 & 24 & 15 & 70 & 258 & 5 & 70 & 0,737 \\
\hline 21 & IV & Y1-4 & $\begin{array}{l}\text { Occupational } \\
\text { Complexity }\end{array}$ & 0 & 6 & 25 & 24 & 15 & 70 & 258 & 5 & 70 & 0,737 \\
\hline 22 & I & $\mathrm{X} 1-7$ & Labor Analysis & 0 & 7 & 23 & 27 & 13 & 70 & 256 & 5 & 70 & 0,731 \\
\hline 23 & I & $\mathrm{X} 1-9$ & $\begin{array}{c}\text { Relationship between } \\
\text { Activities }\end{array}$ & 0 & 4 & 30 & 23 & 13 & 70 & 255 & 5 & 70 & 0,729 \\
\hline 24 & II & $\mathrm{X} 2-3$ & $\begin{array}{c}\text { Ineffective } \\
\text { Communication }\end{array}$ & 0 & 6 & 26 & 28 & 10 & 70 & 252 & 5 & 70 & 0,720 \\
\hline 25 & II & $\mathrm{X} 2-1$ & Labor Reduction & 0 & 8 & 25 & 27 & 10 & 70 & 249 & 5 & 70 & 0,711 \\
\hline 26 & I & $\mathrm{X} 1-2$ & $\begin{array}{l}\text { Design Change or } \\
\text { Design Error }\end{array}$ & 0 & 8 & 25 & 28 & 9 & 70 & 248 & 5 & 70 & 0,709 \\
\hline 27 & I & $\mathrm{X} 1-8$ & Repeated Job Analysis & 0 & 8 & 26 & 26 & 10 & 70 & 248 & 5 & 70 & 0,709 \\
\hline 28 & $\mathrm{~V}$ & Y2-1 & $\begin{array}{l}\text { Lack of Knowledge } \\
\text { about Materials }\end{array}$ & 0 & 6 & 29 & 26 & 9 & 70 & 248 & 5 & 70 & 0,709 \\
\hline
\end{tabular}

\begin{tabular}{|c|c|c|c|c|c|c|c|c|c|c|c|c|c|}
\hline \multirow[t]{2}{*}{ RANK } & \multirow{2}{*}{$\begin{array}{l}\text { MAIN } \\
\text { FACTO } \\
\quad \text { R }\end{array}$} & \multirow{2}{*}{$\begin{array}{l}\text { SUBFA } \\
\text { CTOR }\end{array}$} & \multirow[t]{2}{*}{ ITEM KSF } & \multicolumn{5}{|c|}{$\begin{array}{c}\text { RECAPITULATION } \\
\text { OF QUESTIONARY } \\
\text { RESULTS } \\
\end{array}$} & \multirow[t]{2}{*}{ TOTAL } & \multirow[t]{2}{*}{ W } & \multirow[t]{2}{*}{$\mathbf{S}$} & \multirow[t]{2}{*}{$\mathbf{R}$} & \multirow{2}{*}{$\begin{array}{l}\text { INDE } \\
\text { X RII }\end{array}$} \\
\hline & & & & 1 & 2 & 3 & 4 & 5 & & & & & \\
\hline 29 & I & $\mathrm{X} 1-5$ & $\begin{array}{c}\text { Delay in the Design } \\
\text { Document Revision and } \\
\text { Approval }\end{array}$ & 1 & 6 & 28 & 27 & 8 & 70 & 245 & 5 & 70 & 0,700 \\
\hline 30 & I & $\mathrm{X} 1-10$ & Minimum Waiting Time & 3 & 6 & 25 & 27 & 9 & 70 & 243 & 5 & 70 & 0,694 \\
\hline 31 & V & Y2-2 & $\begin{array}{l}\text { Supplier Performance in } \\
\text { Material Supply }\end{array}$ & 1 & 7 & 29 & 24 & 9 & 70 & 243 & 5 & 70 & 0,694 \\
\hline 32 & III & $\mathrm{X} 3-3$ & $\begin{array}{c}\text { Decreasing Groundwater } \\
\text { Level }\end{array}$ & 2 & 7 & 29 & 22 & 10 & 70 & 241 & 5 & 70 & 0,689 \\
\hline 33 & III & $\mathrm{X} 3-1$ & $\begin{array}{c}\text { Availability of Work } \\
\text { Equipment as needed, } \\
\text { such as TBM, Launching } \\
\text { Girder, etc. } \\
\end{array}$ & 1 & 9 & 27 & 25 & 8 & 70 & 240 & 5 & 70 & 0,686 \\
\hline 34 & II & X2-7 & Unclear details & 2 & 7 & 29 & 24 & 8 & 70 & 239 & 5 & 70 & 0,683 \\
\hline 35 & II & $\mathrm{X} 2-9$ & Work location & 2 & 7 & 32 & 22 & 7 & 70 & 235 & 5 & 70 & 0,671 \\
\hline
\end{tabular}

\section{CONCLUSION}

From this RII analysis, 10 factors that have the most influence on the delay in LRT structure work are obtained :

1. Weak Project Planning and Scheduling by Contractors

2. Project Time Optimization

3. Not Effective Planning and Scheduling

4. Determination of Time Duration

5. Contractors who lack experience

6. Weak Communication and Poor Coordination by Service Users during Construction

7. Different Underwater Layers

8. Solid, crowded and other disturbances in the field 
9. Low Quality of Project Control

10. Lack of Control

\section{REFERENCES}

1. M. Haming and M. Nurnajamuddin, Manajemen Produksi Modern. Jakarta: Bumi Aksara, 2007.

2. K. R. Baker and D. Trietsch, Principles of sequencing and scheduling: John Wiley \& Sons, 2013.

3. M. Firdaus, I. Masudin, and D. M. Utama, "Penjadwalan Flowshop Dengan Menggunakan Simulated Annealing," Spektrum Industri, vol. 13, 2015.

4. Praboyo B. 1999. Keterlambatan Waktu Pelaksana Proyek. Klasifikasi dan Peringkat dari Penyebab-penyebabnya. Dimensi Teknik Sipil. (1). 49-58.

5. Tarore H, Mandagi R. J. M., 2006. Sistem Manajemen Proyek dan Konstruksi (SIMPROKON), Tim Penerbit JTS Fakultas Teknik UNSRAT, Manado

6. Soedrajat, A. S., 1994. Analisa Anggaran Biaya Pelaksanaan (Cara Modern). Nova, Bandung.

7. Ervianto, W. I., 2004. Teori-Aplikasi Manajemen Proyek Konstruksi. Penerbit Andi, Yogyakarta

8. Mercyano Febrianda, I. W. (2013). 'Studi Perencanaan LRT (Light Rail Transit) Sebagai Moda Pengumpan (Feeder) MRT Jakarta'. Jurnal Teknik Pomits, Volume 1 (1), pp. 1-6

9. Sompie, B. F., Wowor, N., 1993. Manajemen Proyek 1., Cahaya Putra, Manado

10. Hardjomuljadi, Sarwono. (2014). Factor Analysis on Causal of Construction Claims and Disputes in Indonesia (with reference to the construction of hydroelectric power project in Indonesia). International Journal of Applied Engineering Research, ISSN 0973-4562, Volume 9, November 22, pp. 12421-12445 